\title{
Isolation and Molecular Identification of Nontuberculous Mycobacterium from Different Species of Fish in Karbala Province, Iraq
}

\author{
Asmaa A B Al-Mashhadani ${ }^{*}$, and Nagham M Al-Gburi² \\ ${ }^{1}$ Public Health Laboratory, Karbala, Iraq, ${ }^{2}$ College of Veterinary Medicine, University of Baghdad, Iraq
}

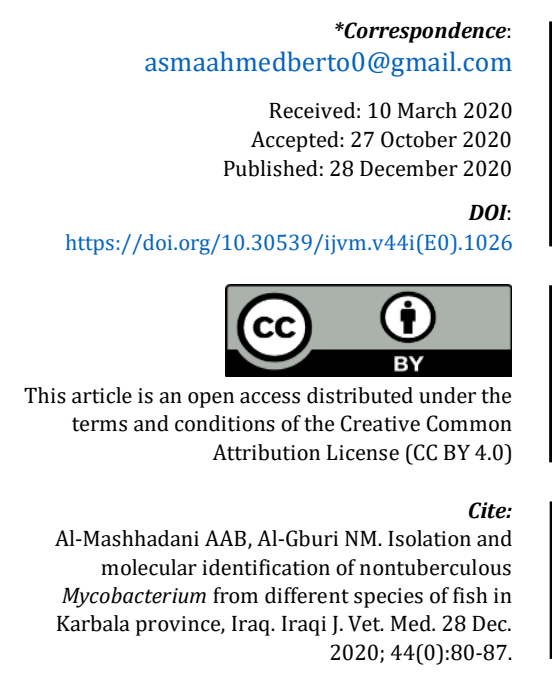

$2020 ; 44(0): 80-87$.

\section{$\begin{array}{llllllllllllllllll}\text { A } & \text { B } & \mathbf{S} & \mathbf{T} & \mathbf{R} & \mathbf{A} & \mathbf{C} & \mathbf{T}\end{array}$}

This study was designed for isolation and molecular identification of Nontuberculous Mycobacterium (NTM) from fish during the period between October and December 2017 from Karbla province, Iraq. This study included 200 fresh fish samples from four different species including Spondyliosoma cantharus, Liza abu, Carassius carassius and Cyprinuscarpio. Three samples of each fish were taken including gills, muscles and all internal organs. The samples were processed by decontamination, concentration of $4 \%$ sodium hydroxide, and $0.1 \mathrm{ml}$ of sediment was streaking on Löwenstein Johnson (LJ) media; then the bacterial cultures were incubated at $28-30^{\circ} \mathrm{C}$ for 3 days up to 4 weeks and suspected colonies were stained with acid fast stain to confirm the presence of Mycobacterium. Further identification, biochemical tests were carried out to confirm the diagnosis of isolates, PCR was done using 16s RNA gene for all isolates, hsp65 gene was used in unidentified NTM spp and to confirm the others. Results revealed that out of 200 fish samples, 19 isolates $9.5 \%$ were identified as NTM belonged to Rapid Growth Mycobacterium (RGM). of the total isolates, $18.26 \%$ was investigated from Liza $a b u$ (Kishni, Abu khraiza). NTM (RGM) isolates on spp level identified six spp of these isolates. M. porcinum was $26.32 \%$ which was followed by M. fortuitum of $21.05 \%$, others included $M$. neworleansense and $M$. mucogenicum $10.5 \%$ of each, $M$. cosmeticum and M. pallens $5.26 \%$ of each. The distribution of NTM spp in the fish organs, nine out of $19(47.37 \%)$ NTM isolate were recovered from gills followed by muscles 36.84 $\%$, while $15.79 \%$ from internal organs. These results were the first study concerning isolation of these spp of NTM from fish in Iraq, and some spp are not reported in other studies. This study concluded that the fish is an importance source or reservoir for NTM, especially the pathogenic spp.

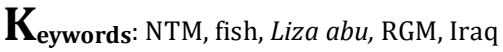

\section{INTRODUCTION}

$\mathrm{N}^{\circ}$ ontuberculous mycobacteria (NTM) infections (mycobacteriosis) affect many aquatic or marine animals (fish, tropical aquarium fish, amphibians, and reptiles) causing chronic diseases, and are considered as a

throughout the body by the circulatory or lymphatic system (1). The average of the incubation period of it is major cause of morbidity and mortality in free-living fish; and infections may lead to production and economic losses. Different clinical signs of mycobacteriosis in fish may be existed depending on the main sites of the infection and its severity or no clinical signs may associate, after invading the mycobacterial organisms into the body and spreading about 3 months and the form of the disease is either acute or chronic. In acute form, the infection is characterized by 
heavy growth of the organism causing death of animals within 16 days (2-4). The chronic form, which is most commonly, is characterized by developing of granuloma in internal organs and animals may survive for maximum of 4 to 8 weeks. Signs may be seen with this disease including exophthalmos (bulging eyes), cachexia, pigmentation in fish body, ulcerative dermal necrosis, skeletal changes, swollen and distended abdomen, ulcers and eroded fins and tail rot, heavy mucus coating on the body surface, loss of scales, loss of appetite, weight loss, non-healing open ulcers, skeletal deformities such as curvature spinal or stunting defect pale gills lethargic. They may detach from other fishes and aggregate in corner of the holding facility (5). Nodular lesions on skin, miliary tubercles occurs in the liver, spleen and kidney which is histologically corresponding to granuloma; in addition to the fact that an affected fish may die, the mortality may reach up to $50 \%$ with no clinical signs $(5,6)$.

Some NTM pathogens that infect fish are highly virulent and are pathogenic to human; so, it may be considered as a zoonotic in a public health concern and its spread from fish, birds, and animals to human causing epidemics in nature (7-13). Conventional biochemical tests are not a significant method for NTM identification at the species level in addition, it waste of time (14). The sequencing of the $16 \mathrm{~S}$ rRNA gene is universally the gold standard method, especially, for significant and rapid identification of NTM for the correct epidemiological control study and treatments, sequencing of the $h s p 65$ gene as the second best alternatives (15-17). This study aimed to isolate and identification of NTM spp. from fish.

\section{MATERIALS AND METHODS}

\section{Sample Collection}

A total of two hundred fresh fish belonged to four fish species were collected from various fish selling markets at Karbala province, Iraq from October to December 2017 from Krabla city. Fish species included were Spondyliosoma cantharus $(\mathrm{n}=35)$, Liza abu $(\mathrm{n}=104)$, Carassius carassius $(\mathrm{n}=46)$, and Cyprinus carpio $(\mathrm{n}=15)$. Fish were autopsied in a biosafety cabinet; an individual set of sterile instruments was used for each animal, $70 \%$ ethanol was applied as anticepsis to the body of the fish. Three samples were taken from each fish included all internal organs (O), Gills (G), and Muscles (M) were removed aseptically, and each part was cut into small pieces then transmitted to sterile porcelain mortar containing sterile normal saline $(0.85 \%)$ have been mashed, then the supernatant transferred into sterile container (18).

\section{Cultivation of Samples and Identification of NTM}

After digestion and decontamination of samples according to (19-21) methods, a loop full of sediment was inoculated to the LJ medium (Hi media, India) and blood agar (Hi media, India) then incubated at $28-30{ }^{\circ} \mathrm{C}$, and the growth observed within 3 days-4 weeks. Ziehl-Neelsen stain (Syrbio, Swiss) was done before and after culturing the samples; and the isolates were identified depending on colonies features, pigmentation production, ability of growth on MacConkey agar without crystal violet $(\mathrm{Hi}$ media, India), in addition to, biochemical tests which included catalase production test (room temperature, semiquantitative catalase), Nitrate reductions, Simmons citrate utilizing, $\mathrm{NaCl}$ tolerance, urea hydrolysis (urease) and arylsulfatase (at three and fourteen days).

Polymerase chain reaction (PCR) was performed after genomic DNA of the bacteria was extracted; and conventional PCR was done to detect two genes in clinical isolates of NTM including: universal primers16S rRNA gene $1400 \mathrm{pb}$ for all isolates by using Forward primer27AGAGTTTGATCTTGGCTCAG, reverse primer -1492 TACGGTTACCTTGTTACGACTT and $h s p 65$ gene $249 \mathrm{pb}$ was used for unidentified Mycobacterium spp.; then to confirm the others, Forward primer-GCCAAGAAGACCGAYGACGT and Reverse primer - GGTGATGACGCCCTCGTTGC were used.

The PCR reaction mixture contained $25 \mu \mathrm{L}$ volume as follows: $12.5 \mu \mathrm{L}$ of PCR premix, $1 \mu \mathrm{L}$ of each forwarded and reversed primers, nuclease free water $8.5 \mu \mathrm{L}$ and $2 \mu \mathrm{L}$ of the template. Then the mixture was amplified using thermocycler [Master cycler-nexus, Eppendorf, Hamburg. Company???] and the program's conditions were as follows: initial denaturation at $95^{\circ} \mathrm{C}$ for $5 \mathrm{~min}$ of one cycle; followed by 35 cycles of denaturation at $95^{\circ} \mathrm{C}$ for $30 \mathrm{sec}$, annealing at $60{ }^{\circ} \mathrm{C}$ for $45 \mathrm{sec}$, and extension at $72{ }^{\circ} \mathrm{C}$ for $1 \mathrm{~min}$; final extension at $72{ }^{\circ} \mathrm{C}$ for $7 \mathrm{~min}$ and hold at $10{ }^{\circ} \mathrm{C}$ for $10 \mathrm{~min}$ (one cycle) (22). While the PCR program for detection of hsp65 was done according to Akbari et al. (23); initial denaturation at $94^{\circ} \mathrm{C}$ for 2 min of one cycle; denaturation at $94{ }^{\circ} \mathrm{C}$ for $30 \mathrm{sec}$, annealing at $62{ }^{\circ} \mathrm{C}$ for $30 \mathrm{sec}$, and extension at $72^{\circ} \mathrm{C}$ for $1 \mathrm{~min}$ ( 40 cycle each); final extension at $72{ }^{\circ} \mathrm{C}$ for $6 \mathrm{~min}$ and hold at $10^{\circ} \mathrm{C}$ for $10 \mathrm{~min}$ (one cycle). After that, $1 \%$ agarose gel electrophoresis was applied to confirm the amplification.

The PCR products were sent to Macrogen Corporation in Korea for Sanger sequencing using an ABI3730XL automated DNA sequencer. The obtained sequences for $16 S$ rRNA gene were analyzed using SepsTest software and compared with known sequences in the GenBank (http://www. ncbi.nlm.nih.gov), EzTaxon-e, the obtained sequences for $h s p 65$ were compared with those present in GenBank, and $h s p 65$-BLAST database (hsp65-BLAST).

\section{RESULTS AND DISCUSSION}

Nineteen isolates $(9.5 \%)$ out of 200 fish samples were identified as NTM; all the isolates belonged to Rapid Growth Mycobacterium (RGM) based on the ability of isolates to 
grow on LJ medium, acid-fast stain, colony characteristics and biochemical tests. The over all of isolates $18.26 \%$ $(19 / 104)$ were investigated only from Liza abu (Kishni, Abu khraiza) which were isolated in December. Seven spp. of NTM on spp. level were identified. M. fortuitum group was the most predominant spp. among fish isolates 15/19 (78.95\%). M. porcinum reported 5/19 (26.32\%) followed by $M$. fortuitum $4 / 19$ (21.05\%), other spp. included $M$. neworleansense and M. mucogenicum 2/19 (10.5\%), M. cosmeticum and M. pallens 1/19 (5.26\%); in addition, three isolates were unidentified on spp. level including (M. septicum, M. peregrinum, M. porcinum, M. neworleansense, M. boenickei, and M. septicum, M. boenickei, M. peregrinum). This result agrees with Abbas (24) who isolated Mycobacterium 64\%, $54 \%$ both of them were belong to RGM from rectal swabs of different fish species;17 (68\%) was from Liza abu in Baghdad province. The above high isolates in comparison to the present result may be attributed to that the samples were from rectum (fecal) which are often harbored and more contaminated with microorganism such as Mycobacterium and depending only on cultural characteristics compared with present study which was more accurately in diagnosis. The results were also in agreement with a study in Nineveh province when it was found that $M$. fortuitum was the most common isolates (10\%), then M. marinum 3.4\% from different fish species belongs to Cypinindae (25). In a survey in NTM of fish from pet shop fish, the common pathogens isolated were $M$. marinum and M. fortuitum ( $M$. fortuitum group) (26). Other study NTM found it was about $11.9 \%$ in freshwater fish tissue and fish products and the NTM spp. were included $M$. porcinum, M. peregrinum, M. fortuitumand, M. phocaicum, and M. mucogenicum (27). As well as M. porcinum and M. septicum, M. peregrinum were identified from infected goldfish, Guppy, and exotic fish species (13).

The distribution of NTM spp. in fish organs, nine out of 19 (47.37\%) NTM isolates were discovered from gills followed by muscles 7 (36.84 \%) while $3(15.79 \%)$ was from internal organs. M. porcinum was frequently isolated from gills and muscles (66.66\%) of each. M. fortuitum $(75 \%)$ was isolated from muscles. M.neworleansense was only isolated from gills and only two M. mucogenicum was isolated from muscles and internal organs, while other spp. had only one isolate of each organ. M. porcinum, $M$. neworleansense, $M$. boenickei, and $M$. septicum, $M$. peregrinum were isolated from gills and M. septicum, $M$. boenickei, M. peregrinum from internal organs (Table 1). This to some extend came in line with a report of NTM were obtained from $1.7 \%$ fish; The species belonged to nine species using sequence analysis of the 16SrRNA gene, which was isolated more frequently from the skin and gills than from muscles or internal organs (28). This is the first time to isolate $M$. neworleansense, $M$. pallens, $M$. cosmeticum and M. boenickei in Iraqi fish. The above spp. habitat in the Iraq environment, including water and the spp. were isolated from gills which might be colonized or transited in the gills although all NTM spp. were isolated in the present study showed to cause infection to man leading to variable clinical signs except for M. pallens (29-32).

Das et al. (11) isolated the NTM from fish associated with granulomatous infection and the most of these pathogens were isolated from skin, gills and other tissues that confirmed by biochemical tests. the above suggested that the infection sound to be affected by the weather temperature, considering that low temperature is favorited for NTM pathogens. The above may agree with other studies in which same NTM spp. were isolated from fish and man in addition to other studies reffering to the possibility of getting infection from fish to man as the fish and its prodects may condiser as an important source of mycobacterial infections. Furthermore, (Kishni, Abu khraiza) reported the harboring of NTM may suggest that fish spp. is most important sources of NTM infections in human $(11,33,34)$.

Table 1. Numbers and percentages of nontuberculous mycobacteria (NTM) spp. isolated from fish internal organs, Gills, and Muscles

\begin{tabular}{|c|c|c|c|c|c|c|}
\hline \multirow{2}{*}{ Nontuberculous mycobacteria spp. } & \multicolumn{2}{|c|}{ Internal organs } & \multicolumn{2}{|c|}{ Gills } & \multicolumn{2}{|c|}{ Muscles } \\
\hline & Number & $\%$ & Number & $\%$ & Number & $\%$ \\
\hline M. porcinum & 1 & 33.33 & 2 & 66.66 & 2 & 66.66 \\
\hline M. fortuitum & - & - & 1 & 25 & 3 & 75 \\
\hline M. neworleansense & - & - & 2 & 100 & - & - \\
\hline M. boenickei & - & - & 1 & 100 & - & - \\
\hline M. porcinum, M. neworleansense, M. boenickei & - & - & 1 & 100 & - & - \\
\hline M. septicum, M. boenickei, M. peregrinum & - & - & - & - & 1 & 100 \\
\hline M. septicum, M. peregrinum & - & - & 1 & 100 & - & - \\
\hline M. mucogenicum & 1 & 50 & - & - & $1(50)$ & 50 \\
\hline M. pallens & - & - & 1 & 100 & - & - \\
\hline M. cosmeticum & 1 & 100 & - & - & - & - \\
\hline Total & 3 & 15.79 & 9 & 47.37 & 7 & 36.84 \\
\hline
\end{tabular}


The cultural characteristics of the NTM isolates of multiplying colony types appeared on the media and the isolates grew at $28-30{ }^{\circ} \mathrm{C}$ within $5-10$ days as range in the first isolation. In sub culturing grew within 5-6 days. $M$. fortuitum group colonies had a smooth white, creamy some of them appeared as a rough, wrinkled, and irregular edge on LJ. In long incubation, it tended to be white to slightly beige, small in diameter and translucent on blood agar for 3 days at $35^{\circ} \mathrm{C}$. M. mucogenicum isolates were mucoid. The colonies of M. pallens and M. cosmeticum isolates had an orange-yellow color, Scotochromogens and the other isolates had non-produced pigmentation neither in dark nor after exposing to light (Figures 1, and 2). All the isolates grew on MacConkey medium without crystal violet except M. pallens; and the reaction on this media were differentiated by lactose ferment (pink) and lactose non ferment (pale yellow).
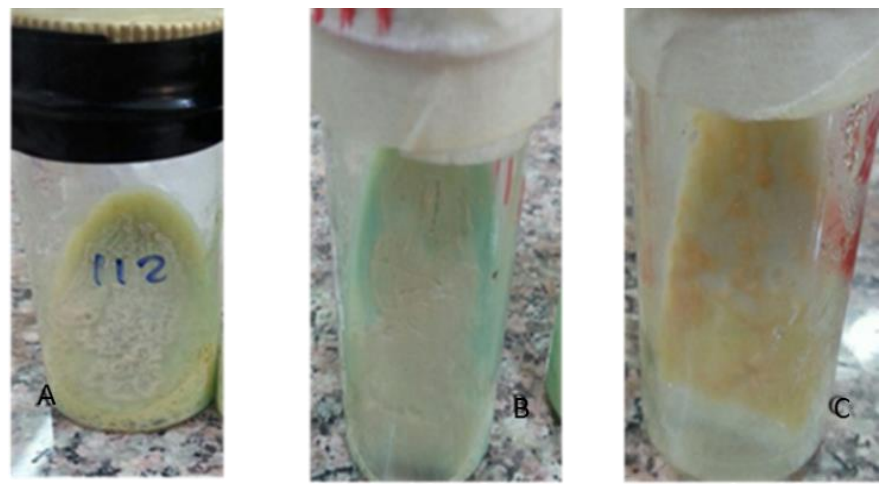

Figure 1. (A) M. fortuitum, rough wrinkled, irregular edged; (B) M. porcinum, white creamy; (C) M. pallens, orange color
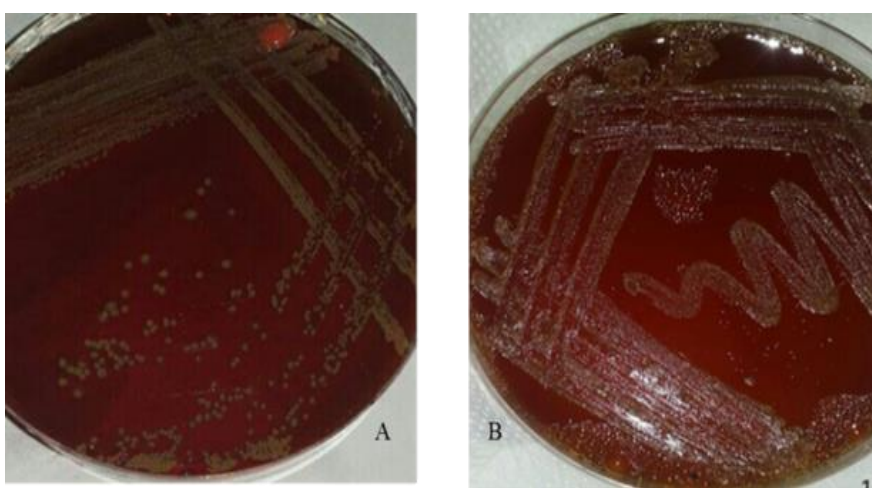

Figure 2. NTM on Blood agar: (A) M. fortuitum, slightly beige and small in diameter colonies; (B) M. bonickei, white to slightly beige, small and translucent colonies

In addition to the above, all the $M$. fortuitum group isolates had pink color while the two isolates M. ucogenicum had a pale yellow; and on acid fast stain, the isolates of NMT were short-long rods and no cord formation, noncapsulated and spore forming (Figures 3 and 4). Biochemical tests revealed these isolates were negative for Simmons' citrate, positive for urease, Catalase test at room temperature and semiquintative catalase $<45 \mathrm{~mm}$. Other biochemical showed differences between isolates as it is shown in (Table 2). These results were similar to the phenotypic characteristics described previously $(16,35,36,37)$. Identification of Mycobacteria is limited by using classical methods such as morphology, growth characteristics and biochemical tests which may give an inaccurate or limited diagnosis due to unreactive biochemical tests, new or novel Mycobacterium spp. discovered causing a confusing to identify at species level $(38,39)$. Moreover, some Mycobacterium spp. are phenotypically similar, causing suspicion in the diagnosis $(40,41)$.

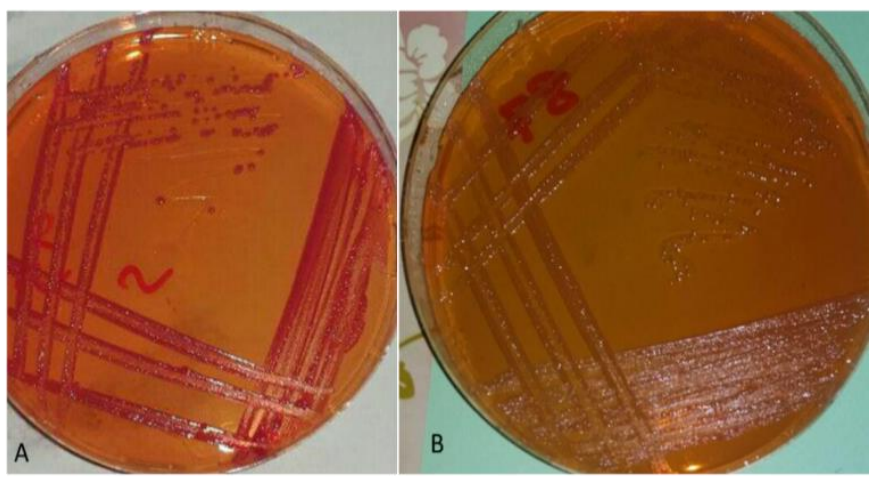

Figure 3. (A) M. fortuitum on MacConkey pink colonies, (B) M. mucogenicum pale yellow colonies
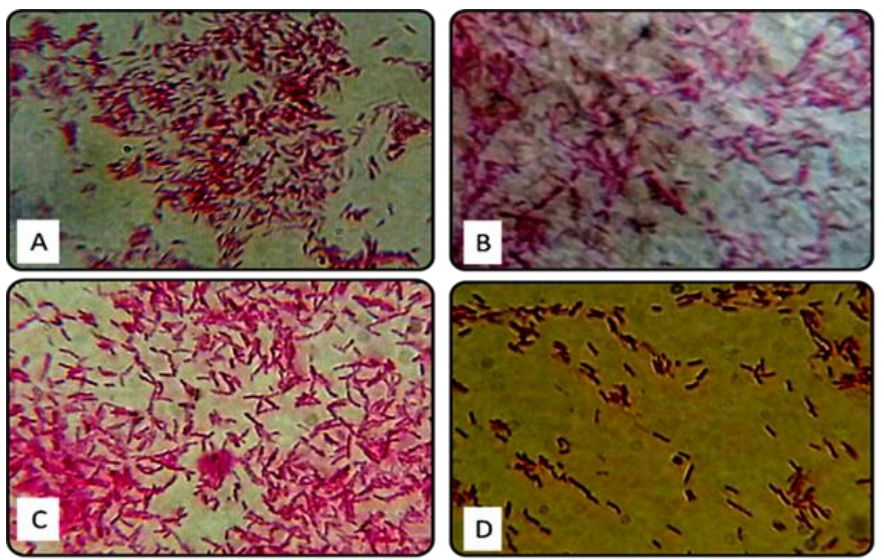

Figure 4. Acid fast bacilli, (A) M. fortuitum, (B) M. pallens, (C) M. neworleansense, (D) M. mucogenicum (100x)

In this study, the same results found variable results in one or two biochemical to the same spp. in different isolates; and in many studies there was also differences in some biochemical test for the same spp. Despite that, some isolates could not be identified at the level of spp. because of high closed relation phylogenetically spp. may lead to a new spp. or novel spp. or need more biochemical tests to confirm differentiated. This result agreed with Bahram et al. (42), although biochemical and phenotypic tests were still the most available facilities for identifying species level in most of microbiological laboratories, the present experiment showed that the results of some of the biochemical tests may be variable and using many colonies and changes in amount of bacterial population would affect the biochemical reaction. 
Table 2. Biochemical tests result of the nontuberculous mycobacteria (NTM) spp

\begin{tabular}{|c|c|c|c|c|c|c|}
\hline No. & Species (No. of isolate) & Nitrate Reduction & $\mathrm{NaCl} 5 \%$ & Catalase test at $68^{\circ} \mathrm{C}$ & Growth on MacConkey & Mannitol sugar agar \\
\hline 1 & M. fortuitum (4) & + & + & 2 -ve, $2+v e$ & +ve, pink & - \\
\hline 3 & M. neworleansense (2) & + & + & + & +ve, pink & + \\
\hline 5 & M. cosmeticum (1) & + & + & + & +ve, pink & - \\
\hline 6 & M. mucogenicum (2) & - & - & - & +ve, pale, yellow & - \\
\hline 7 & M. pallens (1) & - & - & - & -ve & - \\
\hline
\end{tabular}

The 16S rRNA gene was amplified from 19 fish isolates using conventional PCR, which was amplified a product size of approximately $1400 \mathrm{bp}$ (Figure 5). In all cases, the sequence similarity reading for all four public databases ranged between 95.19-100\%. SepsiTest blast ranged between 97.2-100\%, Genebank 96.63-100\%, EzTaxon-e 95.19-10 and 0\% Hsp-BLAST 100\%. According to this database reading in this study, a similarity of $16 \mathrm{~S} r R N A$ or hsp65 gene and 16S rRNA were reported and fish isolates were7 isolates give similarity $100 \%$ : 3 isolates were $M$. fortuitum, 3 isolates were M. porcinum, 1 isolate was $M$. pallens, while 10 isolates give rang of similarity between 95.19-99.9\%: 1 isolate were $M$. fortuitum, nine isolates were each isolate was gave vary between two or three species (Table 3). This isolate can be differentiated using biochemical test on isolate even if biochemical test could not be differentiated on level spp. Finally, the other two isolates divided into one had only $M$. spp., and one was unidentified by $16 S$ rRNA. Therefore, $h s p 65$ gene to detect 5 spp. was used and this gene gave $100 \%$ similarity to these isolates with exception to two isolates in which they varied between two or three spp. These isolates were not differentiated on spp. level as shown in Table 3 even by biochemical test. In study of Joao et al., (43) mycobacteria based on two highly conserved genes $16 S$ rRNA and hsp65 were used to identify the gen and several public databases to perform the data analysis explaining the cause of using two genes, the $16 S$ rRNA which is universally used for bacteria identification. Nevertheless, this has several limitations even so it is rare in some cases (M. terrae and $M$. celatumcomplex); and two copies of the $16 S$ rRNA gene, with different sequences, could be found in the same mycobacteria (44). Williams et al. (45) used "16S rRNA sequence analysis for successful performance of 30 NTM isolates giving results of two isolates to fail of show $16 S$ rRNA PCR product and in this study, the identification was taken as the closest match generated by GenBank blast search analysis, had similarities ranged from 96 to $100 \%$ homology over fragment sizes of 448 to $635 \mathrm{bp}$. They explained the above as there were no standards for the interpretation and analysis of sequence data in a diagnostic setting.

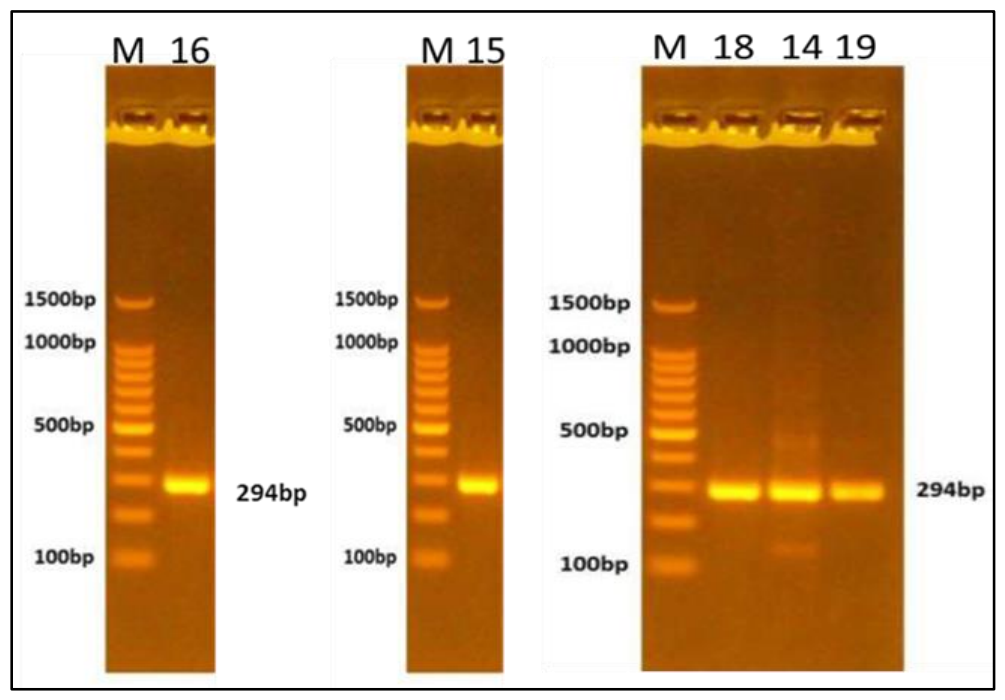

Figure 5. Results of presence of $h s p 65$ gene with $294 \mathrm{bp}$, fractionated on $1 \%$ agarose gel electrophoresisstained withethidium bromide. Lane $M=100$ bp DNA ladder. Lanes $14,15,16,18$, and $19=$ positive isolates

Therefore, all results should be interpreted on an individual basis in conjunction with the clinical information; and sequence analysis of $16 S$ rRNA did not differentiate among M. peregrinum, M. septicum and M. fortuitum; M. kansasii and M.gastri; M. mucogenicum and $M$. ratisbonense; $M$. chelonae, $M$. abscessus group and $M$. fuerth and they suggested that the reason is according to what Han et al. (46) has referred to. The inability to distinguish between $M$. 
kansasii and M. gastri using $16 S$ rRNA gene sequence analysis has been noted previously, however, these species could be differentiated by culture characteristics.

The study concluded that fish is a potential source of pathogenic NTM spp. that may increase the risk of public health. In addition to that, using sequence analysis for hsp65 gene with 16S rRNA primer and using multiple public databases are good methods for identifying NTM at the species' level.

Table 3. Results of Sequences Analysis and Identification of nontuberculous mycobacteria (NTM)S of Fish isolates by four databases

\begin{tabular}{|c|c|c|c|c|}
\hline & \multirow[b]{2}{*}{ Identification } & \multicolumn{3}{|c|}{$\begin{array}{l}\text { 16S rRNA } \\
\text { (similarity\%) } \\
\text { 1: sepsiTest blast 2: GenBank, 3: EzTaxon-e }\end{array}$} \\
\hline & & 1 & 2 & 3 \\
\hline 1 & $\begin{array}{l}\text { M. porcinum } \\
\text { M. neworleansense }\end{array}$ & 100 & 99.9 & 99 \\
\hline 2 & M. fortuitum & 100 & 100 & 100 \\
\hline 3 & $\begin{array}{l}\text { M. porcinum } \\
\text { M. neworleansense }\end{array}$ & 99.3 & 99.3 & 99.3 \\
\hline 4 & $\begin{array}{l}\text { M. porcinum } \\
\text { M. neworleansense } \\
\text { M. boenickei } \\
\end{array}$ & 99.7 & 99.7 & 99.7 \\
\hline 5 & M. fortuitum & 100 & 100 & 99 \\
\hline 6 & $\begin{array}{l}\text { M. porcinum } \\
\text { M. neworleansense } \\
\text { M. boenickei } \\
\end{array}$ & 99.7 & 99.7 & 99.8 \\
\hline 7 & $\begin{array}{l}\text { M. porcinum } \\
\text { M. neworleansense }\end{array}$ & 99.8 & 98.8 & 99.8 \\
\hline 8 & $\begin{array}{l}\text { M. porcinum } \\
\text { M. neworleansense }\end{array}$ & 100 & 99.9 & 99 \\
\hline 9 & M.porcinum & 100 & 100 & 100 \\
\hline 10 & M. fortuitum & 100 & 100 & 100 \\
\hline 11 & M. fortuitum & 99.5 & 95.5 & 99 \\
\hline 12 & M.pallens & 100 & 100 & \\
\hline 13 & M. porcinum & 100 & 100 & 100 \\
\hline 14 & $M$. spp. & $=$ & $=$ & \\
\hline 15 & $\begin{array}{l}\text { M. phocaicum } \\
\text { M. mисовеnicum }\end{array}$ & 99.8 & M. mисовеnicum 99.6 & $\begin{array}{l}\text { M. peregrinum } \\
\text { M. conceptionense } \\
\text { M. montmartrense } \\
99.47 \\
\end{array}$ \\
\hline 16 & $\begin{array}{l}\text { M. phocaicum } \\
\text { M. mucogenicum }\end{array}$ & 97.2 & $\begin{array}{l}\text { M. mucogenicum } \\
96\end{array}$ & $\begin{array}{l}\text { M. mucogenicum } \\
96.63\end{array}$ \\
\hline 17 & M.porcinum & 100 & M. mucogenicum 99.6 & M. mucogenicum \\
\hline 18 & $\begin{array}{l}\text { M. porcinum } \\
\text { M. neworleansense } \\
\text { M. boenickei }\end{array}$ & 98.6 & 96 & $\begin{array}{l}\text { M. porcinum } \\
95.19\end{array}$ \\
\hline
\end{tabular}

19 Unidentified by $16 \mathrm{~S}$ rRNA

\begin{tabular}{|c|c|c|}
\hline \multicolumn{2}{|c|}{$\begin{array}{l}\text { hsp } 65 \text { gene sequencing } \\
\text { (similarity\%) } \\
\text { 1: GenBank, 2: Hsp -BLAST }\end{array}$} & \multirow[t]{2}{*}{$\begin{array}{l}\text { Differentiated by } \\
\text { Biochemicals }\end{array}$} \\
\hline 1 & 2 & \\
\hline Not done & Not done & M. porcinum \\
\hline Not done & Not done & M. fortuitum \\
\hline Not done & Not done & M. neworleansense \\
\hline Not done & Not done & $\begin{array}{l}\text { M. porcinum } \\
\text { M. neworleansense } \\
\text { M. boenickei } \\
\end{array}$ \\
\hline Not done & Not done & M. fortuitum \\
\hline Not done & Not done & M. boenickei \\
\hline Not done & Not done & M. neworleansense \\
\hline Not done & & M. porcinum \\
\hline 100 & & M. porcinum \\
\hline \multirow[t]{2}{*}{100} & & M. fortuitum \\
\hline & & M.pallens \\
\hline 100 & & M. porcinum \\
\hline \multirow[t]{2}{*}{$\begin{array}{l}\text { M. cosmeticum } \\
100\end{array}$} & $\begin{array}{l}\text { M. cosmeticum } \\
100\end{array}$ & M.cosmeticum \\
\hline & $\begin{array}{l}\text { M. mисоgenicum } \\
100\end{array}$ & M. mucogenicum \\
\hline $\begin{array}{l}\text { M. mucogenicum } \\
100\end{array}$ & $\begin{array}{l}\text { M. mисовеnicum } \\
100\end{array}$ & M. mucogenicum \\
\hline 100 & 100 & M. porcinum \\
\hline M. septicum & M. septicum & M. septicum \\
\hline M. peregrinum & M. boenickei & M. boenickei \\
\hline $\begin{array}{l}\text { M. boenickei } \\
100\end{array}$ & 100 & \\
\hline M. septicum & M. septicum & M. septicum \\
\hline M. peregrinum & M. boenickei & M. boenickei \\
\hline $\begin{array}{l}\text { M. boenickei } \\
100\end{array}$ & 100 & M. peregrinum \\
\hline
\end{tabular}

2. Janik JP, Bang RH, Palmer CH. Successful treatment of Mycobacterium marinum infection with minocycline after complication of disease by delayed diagnosis and systemic steroids. J Drugs Dermatol. 2005; 4(5): 621-624.

3. Tobin DM, Ramakrishnan L. Comparative pathogenesis of Mycobacterium marinum and Mycobacterium tuberculosis. Cell Microbiol. 2008; 10(5): 1027-1039.

4. Lara-Flores M, Aguirre-Guzman G, Balan-Zetina SB, Sonda-Santos $\mathrm{KY}$, Zapata AA. Identification of Mycobacterium agent isolated from tissues of nile tilapia (Oreochromisniloticus). Turk J Fish Aquat Sci. 2014; 14(2): 575-580.

5. Ghittino C, Latini M, Agnetti F, Panzieri C, Lauro L, Ciappelloni R, et al. Emerging pathologies in aquaculture: effects on production and food safety. Vet. Res. Commun.2003;27(1): 471-479.

6. Gauthier DT, Rhodes M W. Mycobacteriosis in fishes: a review. Vet J. 2009;180(1): 33-47.

7. Novotny L,Halouzka R, Matlova L,Vavra O, Bartosova L, Slany M, et al. Morphology and distribution of granulomatous inflammation in freshwater ornamental fish infected with mycobacteria. J Fish Dis. 2010; 33(12): 947-955.

8. Willson S J, Kaufman M G, Merritt R W, Williamson H R, Malakauskas D M, Benbow M E. Fish and amphibians as potential reservoirs of Mycobacterium ulcerans, the causative agent of Buruli ulcer disease. Infect Ecolo Epidemiolo.2013; 3(1): 19946. 
9. Woodhouse SJ, Fitzgerald SD, Lim A, Bolin, SR. Disseminated Mycobacterium haemophilum infection in an Assam trinket snake (Elaphefrenata). J Zoo Wildl Med. 2014; 45(4): 966-969.

10. Chang CT, Whipps CM. Activity of antibiotics against Mycobacterium species commonly found in laboratory zebrafish. J Aquat Anim Health. 2015; 27(2): 88-95.

11. Das $\mathrm{P}, \mathrm{Saha} T$, Sengupta T. A detailed report on mycobacteriosis in Pampus argenteus along the coast of Bay of Bengal, West Bengal, India J Coast Life Med. 2016; 4(10): 760-764.

12. Barrows M, Koeppel K, Michel A, Mitchell E. Mycobacterial arthritis and synovitis in painted reed frogs (Hyperoliusm armoratus). J Comp Pathol. 2017; 156(2-3): 275-280.

13. Gcebe N, Michel AL, Hlokwe TM. Non-tuberculous Mycobacterium species causing mycobacteriosis in farmed aquatic animals of South Africa. BMC Microbiol.2018; 18(1):32.

14. Springer B,Tortoli E, Richter I,Grünewald R,Rüsch-Gerdes S,Uschmann K, et al. Mycobacterium conspicuum sp. nov., a new species isolated from patients with disseminated infections. J Clinic Microbiol. 1995; 33(11): 2805-2811.

15. Lee ES, Lee MY, Han SH, Ka J O. Occurrence and molecular differentiation of environmental mycobacteria in surface waters. J Microbiol Biotechnol.2008; 18(7): 1207-1215.

16. Tortoli E. Standard operating procedure for optimal identification of mycobacteria using 16S rRNA gene sequences. Stand Genomic Sci. 2010; 3(2): 145.

17. Simmon KE, Brown-Elliott BA, Ridge PG, Durtschi JD, Mann LB, Slechta ES, et al. Mycobacterium chelonae-abscessus complex associated with sinopulmonary disease, Northeastern USA. Emerg Infect Dis. 2011; 17(9): 1692.

18. Pfyffer GE. Mycobacterium: general characteristics, laboratory detection, and staining procedures. James HJ, Karen CC, GF, Michael AP, Marie LL, Sandra S R, David W, editors. In Manual of Clinical Microbiology, $7^{\text {th }}$ ed. Am Soc Microbiol. 2015;536-569.

19. Petroff S A. A new and rapid method for the isolation and cultivation of tubercle bacilli directly from the sputum and feces. J Exp Med. 1915;21(1): 38-42.

20. Cruickshank R, editor. The practice of medical microbiology. $12^{\text {th }}$ ed. Edinburgh; New York, New York.: Churchill Livingstone; $1975.390 \mathrm{p}$.

21. Abbas M. Isolation of Mycobacteria spp. from rats. Iraqi J. Vet. Med. 2008; 32(2): 60-67.

22. Mukherjee S, Kumar D, Nanda A K, Chakraborty R. 16 S rRNA gene sequence analyses of the metagenome derived from waters of river Mahananda at Siliguri: An approach to understand bacterial diversity. Indian J Biotechnol.2013; 12: 80-87.

23. Akbari S, Mosavari N, Tadayon K, Rahmati-Holasoo H. Isolation of Mycobacterium fortuitum from fish tanks in Alborz, Iran. Iran J Microbiol.2014; 6(4): 234.

24. Abbas M S. Isolation of Mycobacterium spp. from Fish. Anbar J Vet. Sci. 2012;5(1): 1-9.

25. Ali HH, Hamad MA. Isolation and diagnosis of mycobacteria species in local water fish in Nineveh province. IJVS.2005; 19(1): 21-26.

26. Kušar D, Zajc U,Jenčič V,Ocepek M, Higgins J, Žolnir-Dovč M, et al. . Mycobacteria in aquarium fish: results of a 3-year survey indicate caution required in handling pet-shop fish. J Fish Dis.2017; 40(6): 773-784.

27. Lorencova A, Klanicova B, Makovcova J, Slana I, Vojkovska H, Babak $\mathrm{V}$, et al. Nontuberculous mycobacteria in freshwater fish and fish products intended for human consumption. Foodborne Pathog Dis.2013; 10(6): 573-576.

28. Mrlik V, Slany M, Kubecka J, Seda J, Necas A, Babak V, et al. A low prevalence of mycobacteria in freshwater fish from water reservoirs, ponds and farms. J Fish Dis.2012;35(7): 497-504.

29. Schinsky MF, Morey RE, Steigerwalt AG, Douglas MP, Wilson RW, Floyd MM, et al. Taxonomic variation in the Mycobacterium fortuitum third biovariant complex: description of Mycobacterium boenickei sp. nov., Mycobacterium houstonense sp. nov., Mycobacterium neworleansense sp. nov. and Mycobacterium brisbanense sp. nov. and recognition of Mycobacterium porcinum from human clinical isolates. Int J Syst Evol Microbiol. 2004; 54(5): 1653-1667.

30. Phelippeau M, Djaltou AO, Musso D, Drancourt M. Epidemiology of nontuberculous mycobacteria in French Polynesia. I Clin Microbiol.2015; 53(12): 3798-3804.

31. Varghese B, Enani M, Shoukri M, AlThawadi S, AlJohani S, Al-Hajoj $\mathrm{S}$. Emergence of rare species of nontuberculous mycobacteria as potential pathogens in Saudi Arabian clinical setting. PLoS Negl Trop Dis.2016; 11(1): p. e0005288.

32. Chanda-Kapata P, Kapata N, Klinkenberg E, Mulenga L, Tembo M, Katemangwe P. Non-tuberculous mycobacteria (NTM) in Zambia: prevalence, clinical, radiological and microbiological characteristics. BMC Infec. Dis. 2015; 15(1): 500.

33. Prearo M, Zanoni RG, Dall'Orto BC, Pavoletti E, Florio D, Penati V. Mycobacterioses: emerging pathologies in aquarium fish. Vet.Res.2004;28: 315-317.

34. Shukla S, Sharma R, Shukla SK. Detection and identification of globally distributed mycobacterial fish pathogens in some ornamental fish in India. Folia Microbiol.2013; 58(5): 429-436.

35. Markey BK, Leonard FC, Achambault M, Cullinana A, Maguire,D, editors. Clin. Vet. Microbiol., $2^{\text {nd }}$ Edinburgh London New York Oxford Philadelphia St Louis Sydney Toronto: Mosby. Elsevier Ltd; 2014. 1219-1243p

36. Vyawahare CR, Jadhav S V N R, Misra R N, Gandham NR, Hatolkar S. Incidence of M. mucogenicum Infection in Tertiary Care HospitaL India: Recent Increase in number of NTM cases. Int J Microbio Res. 2017; 9:59-962.

37. Mondragón-Barreto $M$, Vázquez-Chacón C A, Barrón-Rivero $C$, Acosta-Blanco P, JostJr KC, Balandrano S, et al. Comparison among three methods for mycobacteria identification. Saludpública de México. 200042, 484-489.

38. Cook V J, Turenne C Y, Wolfe J, Pauls R, Kabani A. Conventional methods versus $16 \mathrm{~S}$ ribosomal DNA sequencing for identification of nontuberculous mycobacteria: cost analysis. J Clin Microbiol.2003; 41(3): 1010-1015.

39. Schulze-Röbbecke R, Weber A, Fischeder R. Comparison of decontamination methods for the isolation of mycobacteria from drinking water samples. J Microbiolo Meth.1991; 14(3): 177-183.

40. König B,Tammer I, Sollich V, König W. Intra-and interpatient variability of the hsp65 and 16S-23S intergenic gene region in Mycobacterium abscessus strains from patients with cystic fibrosis .J Clin Microbiol.2005; 43(7): 3500-3503.

41. Bahram N E, Ensieh S, Shrareh M, Jamshid F, Hossein F, Ghasemian $\mathrm{SH}$, et al. Isolation and phenotypic identification of nontuberculous mycobacteria existing in Isfahan different water samples.Adv Biomed Res.2012;(1):1-18.

42. Joao I, Cristovao P, Antunes L, Nunes B, Jordao L. Identification of nontuberculous mycobacteria by partial gene sequencing and public databases. Int J Mycobacteriolo. 2014;144-151.

43. Ninet B, Monod M, Emler S, Pawlowski J, Metral C, Rohner P, et al. Two different 16S rRNA genes in a mycobacterial strain. J Clin Microbiol. 1996; 34(10): 2531-2536.

44. Williams KJ, Ling C L, Jenkins C, Gillespie SH, McHugh T D. A paradigm for the molecular identification of Mycobacterium speciesin a routine diagnostic laboratory. J Med Microbial. 2007; 56(5): 598-602.

45.Han X Y, Pham A S, Tarrand JJ, Sood P , Luthra R. Rapid and accurate identification of mycobacteria by sequencing hypervariable regions of the $16 \mathrm{~S}$ ribosomal RNA gene. Am J Clin. Pathol.2002; 118(5): 796-801. 


\title{
العزل والتثخيص الجزيئي للمتفطرات اللاسلية من مختلف أصناف الاسماك في محافظة كربلاء، العراق
}

\author{
اسماء احمد برو1 و نفم محمد عيال2 \\ 1امختبر الصحة العامة، كربلاء، 2كلية الطب البيطري، جامعة بغداد
}

الخلاصة

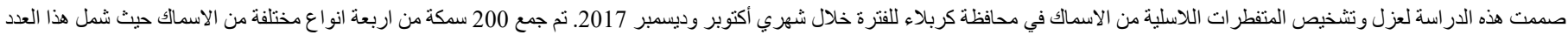

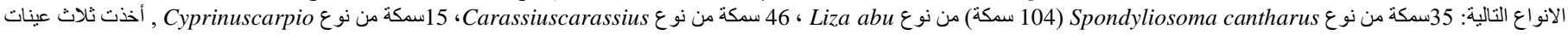

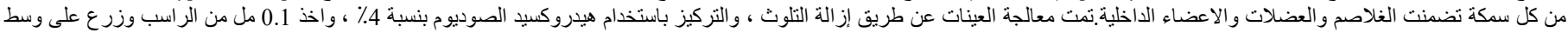

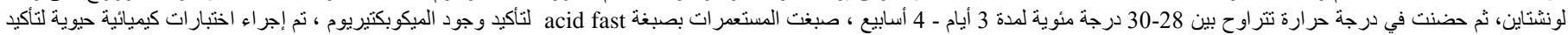

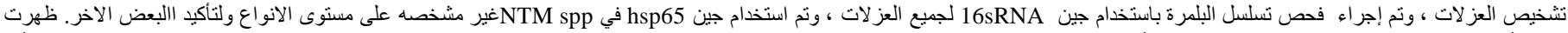

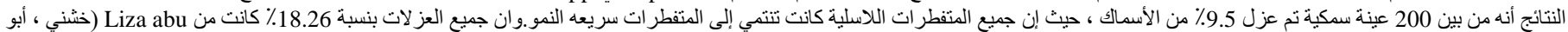

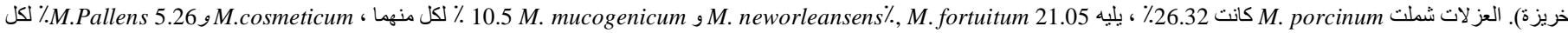

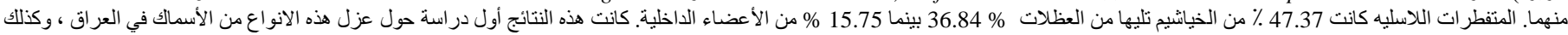

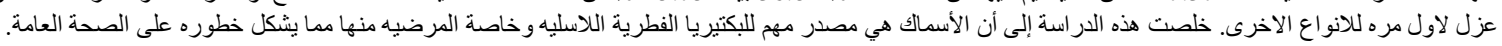

الكلمات المفتاحية: المتفطرات اللاسلية، اسماك، ابو خريزه، خشني، العراق 